УДК 37.091.214:348(477)

DOI: 10.37026/2520-6427-2020-101-1-8-11
Ярослав НАГРИБЕЛЬНИЙ,

кандидат історичних наук, декан факультету судноводіння,

дочент кафедри гуманітарних дисииплін

Херсонської державної морської академії

\title{
ОСМИСЛЕННЯ ІДЕЙ Я. А. КОМЕНСЬКОГО В КОНТЕКСТІ СУЧАСНИХ РЕАЛІЙ
}

У статті проаналізовано педагогічні пращі Я. А. Коменського як феномен педагогічної думки, щчо став точкою відліку для сучасної педагогіки $і \epsilon$ потужною спонукою до переосмислення ци нового прочитання ідей видатного педагога, які мають виняткове значення для сьогодення. Особливу увагу приділено репрезентуванню його педагогічної спадщини в контексті сучасних глобалізаційних змін у суспільстві й освіті. Акиентовано, шо педагог створив низку навчальних книг, зокрема "Відкриті двері до мов $і$ всіх наук» (підручник із латинської мови), «Астрономія», "Фізика», які засвідчують енииклопедичність його знань. Зроблено спробу описати унікальну педагогічну постать Я. А. Коменського як учителя, вихователя, підручникотвория, науковия, філософа, богослова багатогранну особистість, який став не тільки розробником ідей, теорій, принциипів, а й успішним творием класно-урочної системи, побудованої на засадах демократизму й гуманізму, щзо підтверджує свою доиільність і життєздатність понад два століття.

Ключові слова: Я. А. Коменський, дидактика, освіта, виховання, класно-урочна система, принципи, методи навчання, підручник.

В статье проанализировань педагогические труды Я. А. Коменского как феномен педагогической мыслли, что стал точкой отсчета для современной педагогики и является мощным толчком к переосмыслению и новому прочтению идей выдающегося педагога, которые имеют исключительное значение для настоящего. Особое внимание уделено репрезентированию его педагогического наследия в контексте современных глобализачионных изменений в обществе и образовании. Акцентировано, что педагог создал ряд учебных книг, в частности «Открытыле двери к языкам и всем наукам» (учебник по латьни), "Астрономия», "Физика», которые свидетельствуют о энииклопедичности его знаний. Сделана попьтка описать уникальную фигуру Я. А. Коменского как учителя, воспитателя, создателя учебников, ученого, философа, богослова - многогранную личность, который сам стал не только разработчиком идей, теорий, принщипов, но и успешным создателем классно-урочной системы, построенной на принцииах демократизма и гуманизма, которая подтверждает свою иелесообразность и жизнеспособность более двух столетий.

Ключевые слова: Я. А. Коменский, дидактика, образование, воспитание, классно-урочная система, принципь, методы обучения, учебник.
The article analyses pedagogical works of $J$. A. Comenius as a phenomenon of pedagogical idea that became a benchmark on modern pedagogy; they have become a powerful trigger to reconsideration and new reading of ideas of outstanding educator and have remarkable meaning today. Special attention is paid to representation of pedagogical legacy of J. A. Comenius in the context of modern globalizing changes in society and in education. It was emphasized that the educator had developed a series of educational books namely "The gate of languages unlocked» (the textbook of Latin language), "Astronomy», "Physics», proving encyclopedic nature of his knowledge. The innovativeness of J. A. Comenius was commented in his substantiation and development of class-lesson system and principles of education. There were drawn historical and pedagogical parallels between achievements of outstanding educator and interpretation of modern pedagogical phenomena and processes. It was stated that J. A. Comenius was and still is more than just an educator concerned about improvement of school education. He is, first of all, outstanding educator-philosopher who managed to see and anticipate the implications of society's development in education of younger generation. Ideas of J. A. Comenius has been progressive for a long time and influenced greatly local and global pedagogy.

There was made an attempt to describe a unique pedagogical personality of J. A. Comenius as a teacher, educator, textbooks developer, researcher, philosopher, theologian - a multidimensional personality which was not only the developer of ideas, theories and principles, but also a successful creator class-lesson system based on the grounds of humanism and democracy; this system has proved its feasibility and sustainability for more than two centuries.

Key words: J. A. Comenius, didactics, education, upbringing, class-lesson system, principle, methods of education, textbook.

Постановка проблеми. Становлення сучасної освітньої системи в незалежній Україні об'єктивно зумовлює підготовку фахівців, які володіють знаннями про кращі іiі традиції від давнини й до сьогодення. Закономірно, що в цьому контексті виникає необхідність здійснити грунтовний аналіз основ історико-педагогічної науки, зокрема внеску конкретних педагогічних персоналій у розвиток освіти й виховання в різні часові відтинки.

Аналіз наукових досліджень і публікацій. Ретроспективний аналіз спеціальних джерел дав змогу з'ясувати, що українськими вченими введено 
в науковий обіг значну кількість студій, присвячених проблемам становлення й розвитку національної системи освіти й виховання. Стали доступними широкому загалу заборонені в радянську добу праці Б. Грінченка, Г. Ващенка, М. Грушевського, І. Огієнка, С. Русової, С. Смаль-Стоцького, Я. Чепіги та багатьох інших, які заклали підвалини національної освіти, що й актуалізувало дослідження педагогічних здобутків знакових персоналій в історії педагогіки. Проблемі відродження несправедливо забутих педагогічних ідей присвячено значну кількість монографічних, дисертаційних праць (Н. Богданець-Білоскаленко, П. Дроб'язко, В. Кравець, С. Лобода, П. Лузан, М. Стельмахович, В. Федяєва та ін.), окремих статей (О. Адаменко, А. Мовчун, О. Неживий, І. Погребняк та ін.), проте й нині означена проблема не втрачає своєї актуальності.

У контексті глобальних трансформацій та зміни соціальних орієнтирів потребує перегляду, переосмислення й аналізу без ідеологічної конотації педагогічна спадщина значної кількості як зарубіжних, так і українських педагогів. Це передусім стосується творчого доробку Я. А. Коменського та інших знакових персоналій, які зробили значний внесок у розвиток всесвітньої педагогічної думки.

Як свідчить опрацювання спеціальної літератури, вивченню педагогічної спадщини Я. А. Коменського присвячено праці О. Антонової, Т. Варенової, В. Галузинського, М. Гриценка, О. Дубасенюк, М. Євтуха, I. Зайченка, В. Кравця, М. Левківського, П. Лузана, О. Любара, О. Пронікова, С. Сисоєвої, Д. Скільського та ін., у яких висвітлено ідеї класика педагогічної думки всесвітнього значення, описано його внесок у розвиток освіти. Непересічна постать Яна Амоса різною мірою репрезентована в усіх підручниках $\mathrm{i}$ навчальних посібниках з історії педагогіки.

У посібнику «Історія педагогіки» М. Левківського особливу роль відіграє представлення педагогічної спадщини Я. А. Коменського в контексті західноєвропейської педагогіки доби Нового часу та Просвітництва. Зокрема, конкретизовано життєпис видатного педагога, його світоглядні позиції, підсилені особистісними чинниками й енциклопедичними знаннями. Розкрито новаторство Яна Амоса в обгрунтуванні та розробці класно-урочної системи і принципів навчання, акцентовано на принципах побудови підручників педагога.

У посібнику-практикумі «Історія педагогіки» О. Антонова орієнтує студентів на опрацювання педагогічної теорії Коменського шляхом узагальнення знань про стан суспільного розвитку Свропи в добу Просвітництва, засвоєння відомостей про основні етапи його життя й діяльності, систематизації провідних ідей педагогічної теорії видатного чеського педагога.

Попри прагнення авторів навчальної літератури грунтовно висвітлити педагогічні здобутки Я. А. Коменського, сьогодні потребує переосмислення його спадщина з урахуванням сучасних реалій у суспільстві загалом та освіті зокрема.

Мета статті - проаналізувати педагогічні праці Я. А. Коменського як феномен педагогічної думки, що став точкою відліку для сучасної педагогіки і $є$ потужною спонукою до переосмислення й нового прочитання ідей видатного педагога, які мають виняткове значення для сьогодення.
Виклад основного матеріалу. Ще за життя Я. А. Коменський був визнаний автором кращих шкільних підручників і дидактичних творів, що стали точкою відліку в теорії й практиці навчання й виховання. Саме тому сьогодні важливо схарактеризувати особистість видатного педагога як засновника класно-урочної системи навчання, допомогти студентам усвідомити й зрозуміти гуманістично-демократичний характер цієї системи, що значною мірою зумовлено суб' єктивними чинниками: особистісними характеристиками, умовами життя, навчання й виховання тощо.

Зі стислих біографічних коментарів відомо, що народився Я. А. Коменський у заможній родині, однак, рано втративши батьків, навчався спочатку в братській, пізніше, в шістнадцятирічному віці, - у традиційній латинській школі. Те, що він уже в юнацькому віці розпочав навчання в латинській школі, уможливило осмислення й аналіз недоліків змісту, методики навчання, щоправда, школу закінчив із відзнакою. Недаремно згодом педагог називав власні шкільні роки втраченим часом. Особистий негативний досвід, природна спостережливість та аналітичний склад мислення спонукали його до розробки питань, пов'язаних $з$ удосконаленням змісту й організації шкільного навчання.

Показово, що після навчання в німецьких університетах Герборна й Гейдельберга Я. А. Коменський повернувся на рідну землю, де й розпочав педагогічну діяльність в умовах, коли Чехія втратила незалежність, а чеські протестанти піддавалися жорстоким переслідуванням й були вигнані далеко за межі Батьківщини. Ці обставини змусили педагога переїхати до Польщі, де він прожив 28 років і створив значну кількість праць, які з часом здобули визнання в усьому світі. Саме в цей період Я. А. Коменський уперше порушив проблему пошуку шляхів полегшення процесу навчання. Ця ідея зберігає актуальність донині й реалізується шляхом розвантаження навчальних програм з усіх шкільних предметів.

У сучасних соціально-політичних умовах особливої актуальності для українських студентів - майбутніх учителів набуває вияв патріотизму видатного чеського педагога, який прагнув допомогти своєму народові зберегти культурну спадщину предків шляхом покращення освіти й виховання молоді. Ідеї педагога знайшли своє висвітлення в найбільш вагомій праці «Дидактика», написаній первинно чеською мовою, а згодом - у переробленому вигляді перекладеній латинською під назвою «Велика дидактика». Педагог уперше в історії освіти запропонував систему шкіл, побудовану на засадах вікової періодизації розвитку особистості.

Першим освітньо-виховним щаблем, на думку Я. А. Коменського, має бути материнська школа; наступним (для хлопчиків і дівчаток від 6 до 12 років) школа рідної мови, яка покликана давати знання про довкілля. Рідна мова, на думку педагога, є засобом пізнання світу та вдосконалення рівня володіння іншими мовами. Важливим $є$ твердження науковця про те, що рідна мова - це потужний засіб зміцнення й збереження нації. Сучасні студенти мають усвідомити роль мови в житті суспільства й розвитку особистості, а також сформувати переконання про ії важливість та особливе значення.

Третім щаблем, як стверджує Ян Амос, є гімназія або латинська школа для юнаків віком 12-18 років, 
які мали схильність до занять наукою (на думку педагога, гімназія або латинська школа повинна функціонувати в кожному місті). На перший погляд видається, що латинська школа Я. А. Коменського схожа на традиційну латинську школу, яка функціонувала впродовж кількох століть. Однак більш детальний аналіз уможливлює виокремлення певних інновацій, які зближували латинську школу із загальноосвітньою школою Нового часу, де поряд із латинською мовою значне місце відводилося також опануванню фізики, природознавства, а також історії та етики. Згодом почала вивчатися риторика й діалектика.

Останній, четвертий, щабель (вищий ступінь навчання в системі Я. А. Коменського) - це академія і подорож (18-24р.), що припадає на вік змужніння та зрілості. Як зазначає М. Левківський, «за часів Я. Коменського академія мала три традиційні факультети: богословський, юридичний i медичний. Великого значення надавалося забезпеченню вищої школи висококваліфікованими вченими, необхідною літературою... До структури занять (поряд із лекціями) входила обов'язкова система самостійної роботи студентів, а також подорожі, які сприяли розширенню знань і вважалися обов'язковою частиною вищої освіти» [4, с. 45$]$

Прикметно, що висловлені видатним педагогом ідеї успішно реалізуються в освітньому процесі сучасних закладів вищої освіти. В умовах інтенсивних суспільних трансформацій, накопичення обсягів інформації особливої актуальності набуває проблема ефективної організації самостійної роботи студентів, якій відведено значне місце в освітньому процесі. «Лише ті знання, до яких людина прийшла самостійно, через власний досвід, думку й дію, стають дійсно міцним її надбанням», - слушно зазначає П. Підкасистий [5].

Уперше Я. А. Коменський запровадив ступеневу систему навчання в школах, що охоплювала дітей, починаючи 3 раннього дитинства та закінчуючи юнацьким віком. Таку систему згодом назвали класно-урочною. Вона міцно закріпила свої позиції та функціонує донині. В історії педагогічної думки вченого вважають творцем класно-урочної системи навчання. Звичайно, на різних етапах розвитку суспільства система зазнавала різноманітних трансформацій з урахуванням соціального контексту й типологічних характеристик суб'єктів освітнього процесу, однак, незважаючи на це, урок залишався пріоритетною формою навчання у школі. Також педагогом було запроваджено й поняття навчальних чвертей [2].

Видатному вченому належить і перша книга для батьків, що мала назву «Материнська школа». У ній розкриваються особливості виховання дітей у родині. Водночас у праці «Материнська школа, або Про турботливе виховання юнацтва в перші шість років» розглядаються завдання, зміст і методика виховання дітей. Прикметно, що розвитку мовлення дітей присвячено окремий розділ, у якому закцентовано: людина від природи наділена розумом і мовленням, цим вона й відрізняється від тварини, а отже, розум і мовлення необхідно постійно розвивати. Педагог рекомендує формувати мовлення дітей упродовж перших шести років на основі врахування їхніх вікових особливостей: до трьох років ключову увагу варто приділяти правильній вимові, на четвертому-шостому роках життя у процесі споглядання речей - збагачувати мовлення дітей, називаючи все те, що бачить дитина.
Я. А. Коменський пропонує також використовувати ритмічні жарти, поетичні тексти, звертати увагу вихованців на різницю між звичайним мовленням i поезією, розвивати образне мовлення, вчити вірші, використовувати в роботі з дітьми художні розповіді, бесіди, виразно читати та аналізувати байки, казки про тварин, виокремлювати назви знайомих і незнайомих предметів задля збагачення словникового запасу дітей відповідної вікової категорії [2]. Неабияку роль педагог відводив використанню наочності, дотриманню послідовності й наступності в ускладненні матеріалу під час його засвоєння. Згодом методичні настанови трансформувалися в педагогічній теорії в однойменні загальнодидактичні принципи навчання, які й покладено в основу багатьох навчальних книг Я. А. Коменського.

Педагог створив низку навчальних книг, зокрема «Відкриті двері до мов і всіх наук» (підручник із латинської мови), «Астрономія», «Фізика», що засвідчує енциклопедичність його знань.

Визначальною особливістю підручника із латинської мови стала його оригінальна структура: замість традиційних для того часу таблиць відмінювання і дієвідмінювання, правил, винятків учням було подано опис дійсності; процес навчання латинської мови супроводжувався різноманітними цікавими відомостями. Про ефективність такої побудови підручника свідчить той факт, що книжка здобула всесвітнє визнання.

Індуктивний спосіб репрезентування навчального матеріалу лишається на часі й сьогодні як методичний орієнтир для сучасних авторів підручників із різноманітних предметів. Дидактичні механізми переходу від конкретного до абстрактного, від простого до складного в навчанні розкрито в праці «Видимий світ у малюнках», яку розглядають як синтез педагогічних поглядів Я. А. Коменського, екстрапольованих у практичну площину. У книзі чітко виокремлено прагнення автора реалізувати свою ключову педагогічну ідею: діти в процесі шкільного навчання мають здобувати якісні енциклопедичні знання, що відповідають їхнім віковим особливостям. На думку М. Левківського, «це свого роду ілюстрована дитяча енциклопедія первісних знань. Вона містить 150 коротких статей, ілюстрованих малюнками... У цьому підручнику Я. Коменський першим серед педагогів виявив турботу про те, щоб діти одночасно пізнавали слова і речі. Суттєво, що всі коротенькі оповіді для дітей не лише проілюстровані, а й чітко систематизовані. Звичайно, дитяче пізнання вчений розпочинає зі знайомства 3 рослинним і тваринним світом. Завершує він цей процес дитячим ознайомленням із тодішнім світом професій, ремеслами й суспільним життям» [4, с. 46]. Ця книга була особливо популярною поміж педагогами та батьками Західної Європи понад 260 років.

У працях Я. А. Коменського закладено основи вивчення й узагальнення продуктивного досвіду попередників, підтвердженням чого $є$ наявність у його напрацюваннях імен тих, хто висловив цікаву думку стосовно організації, методів навчання та вимог до них.

Особливий інтерес викликає розроблена педагогом проблема вибору методів навчання. Запропонований ним метод навчання був досить простим, мав низку прикметних ознак, сформульованих як правила, що висвітлені в багатьох його творах, насамперед у «Великій дидактиці». Стисло ці правила можна прокоментувати таким чином: у школі необхідно навчати самих речей, а не слів, що їх позначають. 
Це положення сформульовано в «золотому правилі» Я. А. Коменського: усе, що тільки можливо побачити, варто надавати для зорового сприймання; те, що можна почути, - для прослуховування; запахи слід сприймати на нюх; те, що має смак, - пробувати; доступне для дотику - сприймати шляхом дотику. Якщо якісь предмети можна сприймати відразу різними шляхами, то це обов'язково необхідно робити [2]. Таким чином, принцип наочності, обгрунтований видатним педагогом, донині залишається основним загальнодидактичним принципом навчання.

Метод навчання, запропонований Я. А. Коменським, протиставлявся схоластичному, що домінував у тогочасній школі. Зауважимо, що сучасні студенти не повинні сприймати слова видатного педагога буквально, слід прочитувати дидактичні підтексти, у яких насамперед передбачено систематичну навчальну працю дітей, виконання ними домашніх завдань на засадах урахування рівнів їхнього розвитку та інтересів, спрямованих на пізнання довкілля. Якщо зміст і методи навчання будуть адекватними до пізнавальних можливостей учнів, то й процес навчання відбуватиметься у сприятливій атмосфері, а діти навчатимуться із задоволенням. Тільки за таких умов можна сформувати особистість учня, спонукаючи його до накопичення особистісного навчального досвіду. Означена ідея набуває особливої актуальності в сучасних умовах, коли перед освітянами поставлено соціально важливе завдання - забезпечити зростання особистісного досвіду учня.

Принагідно зазначимо, що сучасне тлумачення поняття «дидактика» дещо звужено на відміну від потрактування видатним педагогом. Оскільки його праця називається «Велика дидактика», а в ній порушено не лише проблеми теорії навчання, а й виховання (морального, релігійного, етичного, фізичного), діяльності педагога, організації навчання, можна зробити висновок, що дидактика Я. А. Коменського охоплює практично всі проблеми, які розглядає сучасна педагогіка.

Упродовж багатьох століть Я. А. Коменський був визнаний видатним педагогом і лише в середині XX століття його поціновано як мислителя, філософа, який запропонував концепцію вдосконалення суспільства у праці «Загальні поради про виправлення справ людських», яку завершити авторові не судилося.

Особливий інтерес для педагогів становить також четвертий розділ цієї праці - «Пампедія», присвячений різноманітним аспектам освіти й виховання. Означений розділ синтезує всі ідеї науковця. Основне призначення праці полягало в тому, щоб зорієнтувати тогочасну спільноту у визначенні ефективних шляхів виховання молодого покоління, здатного до вдосконалення суспільства.
Винятково актуальною є висловлена Я. А. Коменським думка про те, що все життя людини має бути школою. Вочевидь визначені ЮНЕСКО сучасні ідеї інформальної освіти (самоорганізованої, або самоосвіти, індивідуальної пізнавальної діяльності на основі життєвого та соціального досвіду) започатковані ще в працях видатного педагога [3].

Висновки. Узагальнення здобутків педагогічної думки уможливлює висновок, що Я. А. Коменський був і залишається не просто педагогом, який вболівав за вдосконалення шкільного навчання, це насамперед видатний педагог-філософ, що зумів побачити й передбачити передумови розвитку суспільства в освіті й вихованні молодого покоління.

На жаль, утрадиційнений виклад матеріалу в навчальній літературі про педагогічні здобутки Я. А. Коменського повною мірою не розкриває наукової вартісності його внеску у світову філософію освіти. Ідеї науковця впродовж тривалого часу були прогресивними й мали вплив не лише на вітчизняну, а й світову педагогіку.

Перспективи подалыших наукових досліджень вбачаємо в переосмисленні педагогічних явищ і процесів, що відбувалися в різні періоди в різних країнах і мають значний вплив на перебіг, зміст та організацію навчання й виховання в сучасних закладах освіти, зокрема положень української етнопедагогіки.

\section{СПИСОК ВИКОРИСТАНОЇ ЛІТЕРАТУРИ}

1. Антонова О. Є. Історія педагогіки. Робочий зошит : посібник-практикум / О. Є. Антонова. - Житомир : Вид-во ЖДУ, 2007. - Вид. 2, доп. і перероб. $120 \mathrm{c}$.

2. Коменский Я. А. Великая дидактика: хрестоматия по истории зарубежной педагогики : [учеб. пос. для студентов пед. ин-тов] / Ян Амос Коменский ; сост. и автор вводных статей А. И. Пискунов. - М. : Просвещение, 1981. - Изд. 2-е, перераб. - 324 с.

3. Концепція освіти дорослих в Україні / укл. Л. Б. Лук'янова. - Ніжин : ПП Лисенко М.М., 2011. $24 \mathrm{c}$.

4. Левківський М. В. Історія педагогіки : підручник / М. В. Левківський. - К. : Центр навчальної літератури, 2006. - Вид. 2, доп. -376 с.

5. Пидкасистый П. И. Самостоятельная познавальная деятельность школьников в обучении: теоретико-экспериментальное исследование / П. И. Пидкасистый. - М. : Педагогика, 1980. - 240 с.

Дата надходження до редакції: 31.01.2020 p. 